\title{
Life Cycle Assessment of Municipal Solid Waste Management - Comparison of Results Using Different LCA Models
}

\author{
Joanna Kulczycka ${ }^{1 *}$, Lukasz Lelek ${ }^{2}$, Anna Lewandowska ${ }^{3}$, Joanna Zarebska ${ }^{4}$ \\ 'Faculty of Management, AGH University of Science and Technology, \\ Aleja Mickiewicza 30, 30-059 Cracow, Poland \\ ${ }^{2}$ The Mineral and Energy Economy Research Institute of the Polish Academy of Sciences, \\ Aleja Wybickiego 7, 31-261 Cracow, Poland \\ ${ }^{3}$ Faculty of Commodity Science, Poznań University of Economics, \\ Aleje Niepodleglości 10, 61-875 Poznań, Poland \\ ${ }^{4}$ Faculty of Economics and Management, University of Zielona Góra, \\ Podgorna 50, 65-246 Zielona Góra, Poland \\ Received: 3 February 2014 \\ Accepted: 15 June 2014
}

\begin{abstract}
LCA is a popular tool widely used to assess the environmental impact of waste management systems, which is illustrated by the substantial number of LCA computer models specifically addressing this subject. Due to the complex nature of waste management modelling and the range of country-specific data, as well as lack of harmonization, it has been observed that there are large discrepancies between the results using different models. Many studies have underlined the necessity of clearly identifying both the scope and methodological assumptions of LCAs in order to have confidence in the results. Therefore, the paper presented here reveals several methodology-related issues. The study tests two different pieces of LCA software, i.e. IWM-2 (designed specifically for MSW) and SimaPro (a generic and widely used LCA software). The pieces of software were used to LCA an MSW scenario and the results obtained (calculated using Ecoindicator'99 H/A) were compared to show the strengths and weaknesses of these tools, i.e., generic software usually treats the waste as a set of separate fractions, not as a whole mass, which means that the software is not highly sensitive to the composition of the waste and does not take into account the environmental impacts produced as a result of the interaction between the waste components after mixing. As waste composition is very important in planning, one study combines these two software packages to get final results, i.e., data generated by IWM-2 were entered into SimaPro. The discussion is built around a case study in Poland where waste management scenarios have been analyzed. The research carried out has shown that having the same initial inventory data collected on the basis of the same assumptions and with the same boundaries to the system model used and using the same method of LCIA to assess the impact on the environment, may not produce the same end results. In the presented study, the main differences in the LCIA results appeared in four output-related impact categories: carcinogens, climate change, ecotoxicity, and eutrophication/acidification, and for one input related impact category - fossil fuels. Four reasons responsible for these differences are identified:

(1) The IWM-2 program identified a smaller number of substances emitted to air and water associated with landfill and recycling than the Ecoinvent database (IWM-2 identified a total of 31 types of emissions to air
\end{abstract}

*e-mail: kulczycka@meeri.pl 
and water for landfill while Ecoinvent identified 405 types, IWM-2 identified 39 types of emissions for recycling while Ecoinvent identified 403 types)

(2) The IWM-2 program did not cover emissions to the soil, while the Ecoinvent database identified 60 types of such impact for landfill and 58 for recycling

(3) The IWM-2 program does not cover consumption of resources, while the Ecoinvent database covered the use of 198 kinds of raw material (including 100 different minerals and fossil fuels)

(4) In each case a different total mass of emissions and resources consumed was identified in the analysis of the inventory included in both analyses.

Keywords: life cycle assessment, municipial solid waste, industrial waste management software, Ecoindicator'99, impact modelling, Poland

\section{Introduction}

In Poland the implementation of EU requirements concerning municipal solid waste management (MSW) is a complex problem, as about $79 \%$ of waste is still landfilled [1-4]. Over the last two years new legislation has been introduced (i.e. amending the Act on maintaining cleanliness and order in the municipality, updating of the Waste Management Act), and the main changes have been in force since 1 July 2013. The law assumes that each municipality is responsible for the collection and the proper treatment of municipal waste, according to the best available techniques, the achievement of EU targets concerning the reduction of mass of municipal waste going to landfill, or the increased recycling of packaging waste. These kinds of targets will be impossible to achieve without constructing and commissioning new plants in the years to come. A plant introducing new technological processes should be ecologically friendly, economically viable, and socially acceptable. The choice of which such solution to adopt should be preceded by appropriate analysis using environmental assessment tools. One kind of tool enabling a comprehensive assessment to be made of the potential impact on the environment is LCA (life cycle assessment). LCA is a process recommended in many EU documents, e.g., Directive 2008/98/EC on waste and repealing certain directives [5-7]. The popularity of the application of LCA to municipal solid waste management systems is illustrated by the substantial number of LCA computer models addressing MSW management. Most of these models have been developed independently from each other and often with features that are specific to the time and geographical conditions in which they were developed. Due to the complex nature of waste management modelling and the range of country-specific data that is required, these models have been developed in relative isolation and consequently suffer from a lack of harmonization. This has produced large discrepancies in the results obtained from different LCA models for waste management [8]. The work of Winkler and Bilitewski [9] was the first to highlight the significant differences between different LCA waste models. They prepared comparative analyses of six prominent LCA models, in which identical input data were used for landfill, incineration, and material recovery scenarios for the waste management system of Dresden, Germany. It was noted that there were very high variations in the predicted emissions. Differences of up to $1400 \%$ in the amounts predicted were identified for some of the results which led to contradictory results from the models [8]. The authors suggest that the transparency of the LCA models needs much improvement, but the identification of the specific differences between each model is not part of the research objectives of their important papers. Another review of LCAs for MSW management systems prepared by Cleary [10] shows that in 20 analyses carried out, 14 computer models were used. Most of these models are process-based, and use databases to supply multiplication factors for model parameters such as landfill gas production. The study underlines the necessity of clearly identifying both the scope and methodological assumptions of LCAs in order to have confidence in the results.

Therefore the paper presented here reveals several methodology-related issues. The study tests two different LCA software packages. IWM-2 software is used to assess the LCA of different variants and its results are compared to those from SimaPro (Eco-indicator 99 method) to show the strengths and weaknesses of these tools and the differences in the LCIA results. This analysis is based on sensitivity analysis by performing LCA calculations using two sources of inventory data: IMW-2 software (with database included) and a general LCA Ecoinvent v.2.0 database included in SimaPro software. The discussion is built around a case study in Poland (Promnik Landfill) where one specific waste management scenario has been analyzed [11].

The following questions were the driving forces of making this comparison: are there any differences in the environmental impacts (consumption of resources, pollutant emissions) calculated by the IWM-2 software and by the SimaPro software using the Ecoinvent database [12] for the waste management scenarios analyzed? How do the potential inventory differences influence the LCIA results?

\section{Review of LCA Software Used for MSW Management}

LCA is a popular tool widely used to assess the environmental impact of product life cycles, technological processes, as well as waste management systems, waste treatment and processes for disposal and recycling [13]. The evaluation of the existing situation of MSW manage- 
ment from an environmental, economic and social perspective via a life cycle approach is an important first step prior to taking any decisions on the technologies to be selected, the policies to be developed and the strategies to be followed for a nation [14]. Results from a life-cycle environmental assessment can be also used to compare the relative environmental impacts of different enterprises, or help to focus efforts toward making environmental improvements to the treatment enterprises [15]. There are many examples of the software tools used to support LCA assessments. There is a general division between generic LCA programs like SimaPro, GaBi, Team, Umberto, and the applications designed specifically for use in one specific area, for example in waste treatment systems: IWM-2 (integrated waste management II), WRATE (waste resources assessment tool for the environment), EASEWASTE (environmental assessment of solid waste systems and technologies), ORWARE (organic waste research), and WISARD (waste - integrated systems for assessment of recovery and disposal). These programs are used both to evaluate existing as well as model new waste management systems. To determine their role, recent papers from the International Journal of Life Cycle Assessment; Waste Management; Resources, and Conservation and Recycling have been reviewed [16-41]. These are focused on using LCA for waste management systems (with the use of tools specially developed for this purpose). It is worth mentioning that most of them were performed using EASEWASTE for those using specifically designed software, and SimaPro and Gabi for those using generic software (Fig. 1).

Differences between the studies in the review are associated with input data, technical assumptions, technology type, inventories used, and output data. It is also observed that the different assumptions in the models are mainly related to the different times when they were developed and the associated knowledge framework (e.g. assumptions for the time horizons for landfill emissions). Further optimization of these tools to geographical conditions will have an additional impact on the results. But each of the LCA programs can demonstrate some advantages and disadvantages if assessed strictly from the waste management point of view. The generic LCA programs often include comprehensive databases, but they are not always specific for the waste treatment systems and fully suitable for nation-

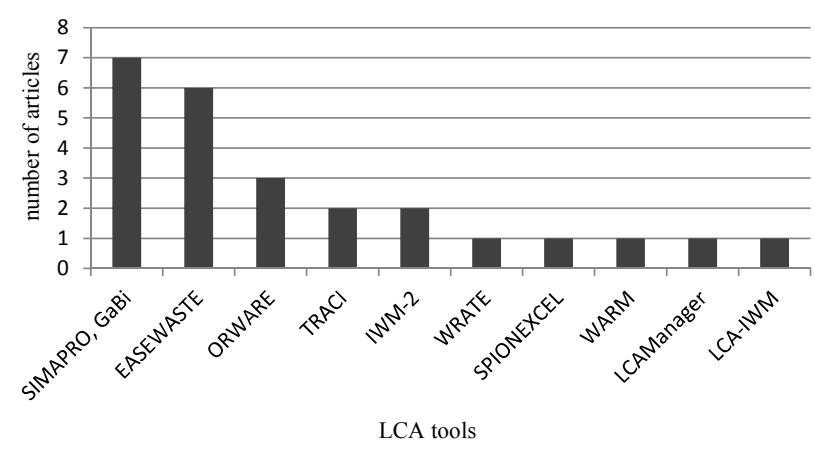

Fig. 1. An overview of case studies of the use of LCA software to assess waste management systems published in recent years (2005-13) [16-41]. $\mathrm{al} /$ regional conditions. Even if waste-oriented inventory data is available, this usually treats the waste as a set of separate fractions, not as a whole mass, which means that the software is not highly sensitive to the composition of the waste and does not take into account the environmental impacts generated as a result of interaction between the waste components after mixing. Another important difference between the software tools lies in the scope of the environmental impacts included in the analysis. IWM-2, for example, embraces emissions to only two compartments: air and water. In the most fully LCA-related software, a wide spectrum of air, water, and soil pollutants are included and further detailing is possible within several outputand input-related impact categories (e.g. respiratory effects, ozone layer depletion, acidification, eutrophication, nonrenewable energy). As a result of an international project (LCA-IWM), IWM-2 has been adopted following the LCA methodology and thanks to it, a "new" LCA-IWM software has gained some additional functionality like performing detailed descriptions within a few impact categories by using the following six characterization factors: abiotic depletion potential (ADP), global warming potential (GWP), photochemical ozone creation potential (POCP), acidification potential (AP), eutrophication potential (EP), and human toxicity potential (HTP) [42]. LCA-IWM therefore has a binary specificity: on the one hand it remains a purely waste-oriented application and on the other it gains an ability to perform impact assessment in accordance with state-of-the-art LCA procedures. However LCA-IWM includes a default set of midpoint characterization factors and it does not allow one to select other life cycle impact assessment approaches. Typical LCA programs usually include many LCIA methods, which make it possible to apply a sensitivity analysis and enable the person carrying out the LCA to make a choice between various approaches to impact modelling.

\section{Study}

The aim of our study is to assess the environmental impact of the municipal waste management process carried out at the Promnik landfill in Poland under different scenarios to monitor their environmental effects. The IWM-2 and SimaPro software packages were used. In order to make the comparison, two LCA analyses were performed:

- LCA1 - the first analysis was based on primary input data concerning the main characteristics of the waste disposal system (manual sorting process for the recycling of secondary raw materials). The input information relating to the morphological composition of the municipal waste was entered in the IWM-2 software (part 1). On the basis of the data entered, the software calculated the emissions from the landfill. The calculations include the total emissions from the landfill and landfill gas to cover the entire "life" of the plant and issues with the waste disposal plant related to recycling, as well as the emissions avoided by this treatment. 
The data generated by IWM-2 (treated as elementary flows) were supplemented by additional primary inventory data relating to land use (treated as an input from nature) and the materials and energy consumption (treated as exchanges with the technosphere).

Both kinds of data were then entered in the SimaPro software and used in LCIA calculations made using the Ecoindicator'99 H/A v.2.06 method (Part 2, Fig. 2).
- LCA2 - in the second analysis all primary data taken from the municipal waste landfill were entered in SimaPro 7.1.8 without previously using IWM-2. The information about landfill specific emissions and other environmental impacts was calculated using the Ecoinvent v.2.0 database included in SimaPro software. Life Cycle Impact Assessment was also made using the Ecoindicator'99 H/A v.2.06 method (Fig. 3).

\section{PART 1}

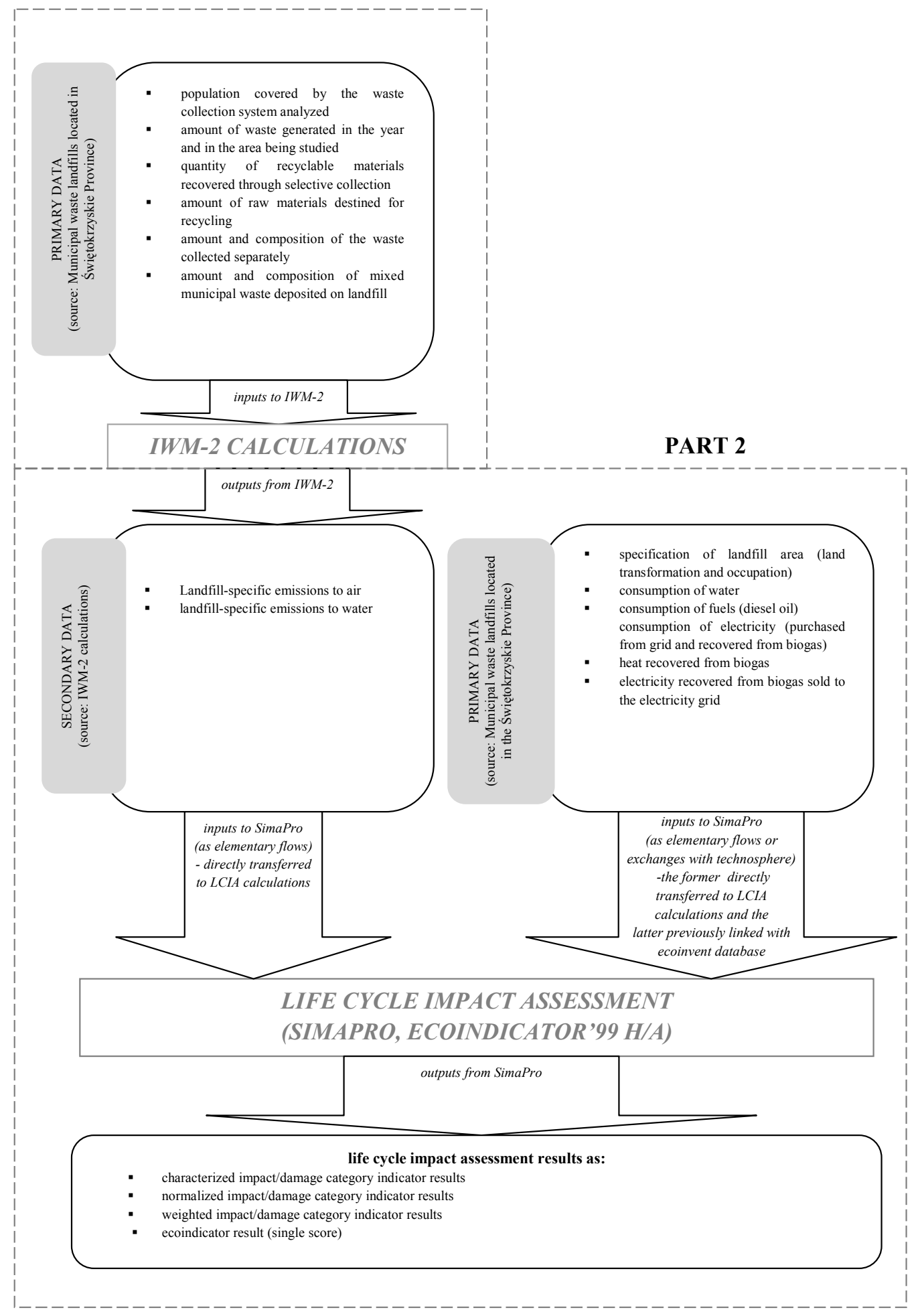

Fig. 2. Procedure for the first life cycle impact assessment based on IWM-2 data (LCA1). 
The boundaries of the system are limited to the landfill site (i.e. sorting waste from separate collection and landfilling municipal mixed waste, recycling material recovered from separate collection, production of energy from recovered biogas). The scope of the analysis is from gate to grave/reincarnation. The following direct environmental impacts are identified in relation to the landfill site and treatment processes: land transformation and occupation, emissions from the landfill of mixed municipal waste, emissions from the production of energy from biogas, emissions from the use of diesel on the landfill site and emissions associated with recycling processes. Secondary (indirect) environmental impacts include the following issues: emissions related to the production of energy bought from the grid for operating the landfill operation (average energy from the grid in Poland) and the emissions associated with the landfill infrastructure (including the system of biogas production). The collection and transportation of waste was excluded from the analysis.

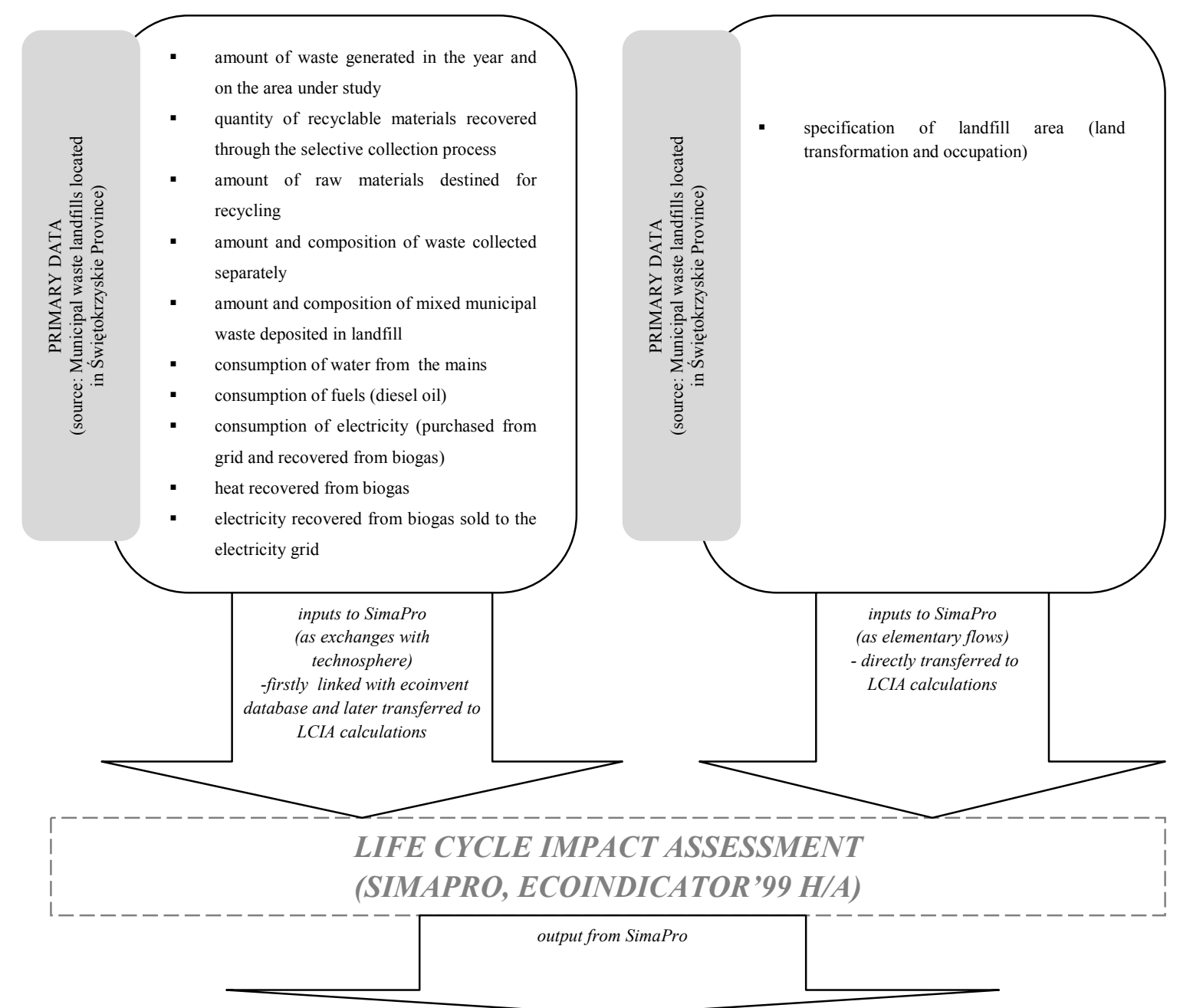

- characterized impact/damage category indicator results

- normalized impact/damage category indicator results

- weighted impact/damage category indicator results

- ecoindicator result (single score)

\section{Functional Unit}

A functional unit of the system is defined as an annual amount $(\mathrm{Mg})$ of municipal waste treated by the Waste Management Company in Promnik, which is estimated at $72,448.6 \mathrm{Mg}$.

\section{Inventory Data}

LCA analysis for the municipal waste landfill in Promnik was conducted using data provided by the Waste Management Company in Kielce. Tables 1-3 present the numbers used in LCA1 and refer to a functional unit. Table 1 shows the information used as input data to IWM-2 (Part 1) while Table 2 presents the emissions calculated by IWM2 and supplementary information relating to land area, the material and energy consumption and energy production from biogas were entered in SimaPro 7.1.8 (Part 2). Table 4 presents the inventory data used in the second LCA analy-

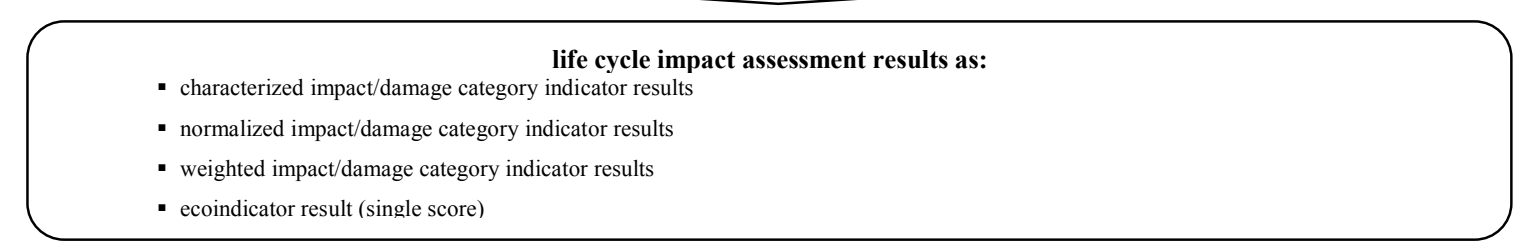

Fig. 3. Procedure for the second life cycle impact assessment based on the Ecoinvent database (LCA2). 
Table 1. Inventory data used as inputs in the calculations made in IWM-2 (LCA1 - part 1).

\begin{tabular}{|c|c|c|c|}
\hline No. & Inventory Elements & Quantity & Unit \\
\hline \multirow{5}{*}{1.} & The composition of the waste collected separately (destined for recycling): & & \\
\hline & paper, packaging paper, and paperboard & 23.10 & $\mathrm{Mg}$ \\
\hline & glass & 310.60 & $\mathrm{Mg}$ \\
\hline & plastic (film) & 18.90 & $\mathrm{Mg}$ \\
\hline & plastic (rigid) & 23.20 & $\mathrm{Mg}$ \\
\hline \multirow{9}{*}{2.} & Composition of mixed municipal waste (destined for landfill): & & \\
\hline & paper, packaging paper, and paperboard & $9,765.90$ & $\mathrm{Mg}$ \\
\hline & glass & 17,87 & $\mathrm{Mg}$ \\
\hline & plastic (film) & $9,374.14$ & $\mathrm{Mg}$ \\
\hline & plastic (rigid) & $1,400.73$ & $\mathrm{Mg}$ \\
\hline & non-ferrous metals & $1,729.70$ & $\mathrm{Mg}$ \\
\hline & ferrous & $1,729.70$ & $\mathrm{Mg}$ \\
\hline & biodegradable waste ( $94.5 \%$ vegetable waste, $5.5 \%$ animal waste) & $14,414.60$ & $\mathrm{Mg}$ \\
\hline & mineral and other & $15,783.9$ & $\mathrm{Mg}$ \\
\hline
\end{tabular}

Source: Primary data taken from the Municipal Waste Management Company in Kielce

sis (LCA2), and also refers to a functional unit. Tables 2 and 4 present data divided into four groups:

- Energy production from biogas

- Servicing of landfill

- Landfill of waste

- Recycling of the waste fractions coming from separate collections

In the case of LCA2, in order to avoid double counting of impacts, the inventory information relating to landfill maintenance and land use was removed from the original Ecoinvent 2.0 inventory tables and primary data presented in Tables 2 and 3 as servicing of landfill has been substituted. In both cases the same functional unit was used and referred to $72,448.6 \mathrm{Mg}$ of waste collected yearly on the area analyzed, of which $99.5 \%(72,072.7 \mathrm{Mg})$ was landfilled and $0.5 \%(375.9 \mathrm{Mg})$ was collected separately and destined for recycling.

\section{An Environmental Impact Assessment for Promnik Landfill}

\section{Life Cycle Impact Assessment (LCIA) Results}

In order to calculate the potential environmental impact the Eco-indicator'99 H/A v. 2.06 method was used to present the following results:

- The cumulative ecoindicator result (a single score) expressed in points $[\mathrm{Pt}]$

- Weighted damage category results expressed in points [Pt] related to three damage categories: human health, ecosystem quality, and resources
- Characterized impact category results expressed in three units DALY (disability adjusted life years), $\mathrm{PDF} \cdot \mathrm{m}^{2}$ year (potentially disappeared fraction $\cdot \mathrm{m}^{2} \cdot$ year) and the surplus energy MJ. The results for 11 impact categories are available in Ecoindicator'99: carcinogens, respiratory effects (organic and inorganic), climate changes, ozone layer depletion, ionizing radiation, ecotoxicity, land use, eutrophication/acidification, minerals, and fossil fuels.

Analyses carried out as LCA1 and LCA2 gave slightly different answers to the question, which concerns the environmental impact associated with the management of municipal waste in Promnik Landfill. In the first case (LCA1) the environmental impacts of the landfill and recycling processes were calculated using IWM-2 software, in the second (LCA2) they come from the Ecoinvent v.2.0 database. The cumulative results of the eco-indicators obtained for both analyses are presented in Fig. 4. The first major difference is the potential impact on the environment expressed by the size of the bars on the figures. It is clear that the result obtained for LCA2 is much higher $(858,415$ $\mathrm{Pt})$ than the result of LCA1 $(95,601 \mathrm{Pt})$. The overall potential environmental impact calculated on the basis of the data from the Ecoinvent v. 2.0 database is almost nine times higher than the impact calculated on the basis of the input from the IWM-2 data for storage and recycling. In both analyses, positive impacts were obtained for the energy production from biogas (- 196,486 Pt), but in LCA1 it is also recorded for recycling $(-11,769 \mathrm{Pt})$. A negative impact on the environment occurred in the operation of the landfill $(100,788 \mathrm{Pt})$ and landfill itself $(\mathrm{LCA} 1=203,069 \mathrm{Pt}$, LCA2 $=943,092 \mathrm{Pt})$. 
Table 2. Inventory data used in LCIA calculations made in SimaPro (LCA1).

\begin{tabular}{|c|c|c|c|c|c|}
\hline & \multicolumn{3}{|c|}{ Inventory Elements } & Quantity & Unit \\
\hline \multirow{6}{*}{ 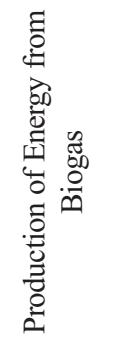 } & \multicolumn{3}{|c|}{ Avoided products } & & \\
\hline & \multicolumn{3}{|c|}{ Heat, from natural gas, at industrial furnace } & $6,003.52$ & MWh \\
\hline & \multicolumn{3}{|c|}{ Electricity, low voltage, at grid, Poland production mix } & $2,572.94$ & MWh \\
\hline & \multicolumn{3}{|c|}{ Own production } & & \\
\hline & \multicolumn{3}{|c|}{ Electricity from biogas (partially used for own purposes, partially sold to the electricity grid) } & $2,572.94$ & MWh \\
\hline & \multicolumn{3}{|c|}{ Heat from biogas (partially used for own purposes, partially sold to the heat grid) } & $6,003.52$ & MWh \\
\hline \multirow{9}{*}{ 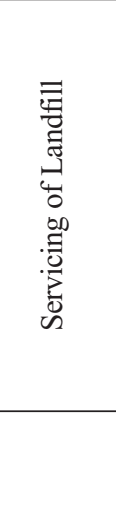 } & \multicolumn{3}{|c|}{ Inputs from nature } & & \\
\hline & \multicolumn{3}{|l|}{ Land transformation } & 4.60 & ha \\
\hline & \multicolumn{3}{|l|}{ Land occupation } & 0.38 & ha×a \\
\hline & \multicolumn{3}{|c|}{ Inputs from technosphere } & & \\
\hline & \multicolumn{3}{|l|}{ Water } & 333.00 & $\mathrm{Mg}$ \\
\hline & \multicolumn{3}{|l|}{ Diesel oil } & 65.00 & $\mathrm{Mg}$ \\
\hline & \multicolumn{3}{|c|}{ Electricity low voltage, at grid, Poland production mix (purchased ) } & 86.00 & MWh \\
\hline & \multicolumn{5}{|c|}{ Outputs to nature (based on IWM-2 calculations) } \\
\hline & \multicolumn{2}{|c|}{ Emissions to air $[\mathrm{kg}]$} & \multicolumn{3}{|c|}{ Emissions to water $[\mathrm{kg}]$} \\
\hline \multirow{12}{*}{ 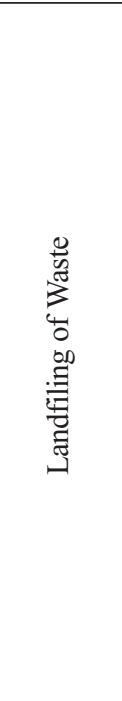 } & $\mathrm{CO}$ & 84.10 & BOD & \multicolumn{2}{|c|}{$12,784.65$} \\
\hline & $\mathrm{CO}_{2}$ & $3,568,278.11$ & COD & \multicolumn{2}{|c|}{$12,784.65$} \\
\hline & $\mathrm{CH}_{4}$ & $1,585,910.35$ & Suspended solids & \multicolumn{2}{|c|}{10.81} \\
\hline & $\mathrm{HCl}$ & 437.32 & TOC & \multicolumn{2}{|c|}{21.61} \\
\hline & $\mathrm{HF}$ & 87.46 & $\mathrm{AOX}$ & \multicolumn{2}{|c|}{21.61} \\
\hline & $\mathrm{H}_{2} \mathrm{~S}$ & $1,345.61$ & Chlorinated Hydrocarbons & \multicolumn{2}{|c|}{11.13} \\
\hline & Hydrocarbons & $1,3456.11$ & Phenols & & \\
\hline & Chlorinated Hydrocarbons & 235.48 & $\mathrm{NH}_{4}^{+}$ & & \\
\hline & Cadmium & 0.04 & As & & \\
\hline & Chromium & 0.01 & $\mathrm{Cd}$ & & \\
\hline & Lead & 0.03 & Chlorides & & \\
\hline & Zinc & 0.50 & $\mathrm{Cr}$ & & \\
\hline & & & $\mathrm{Cu}$ & & \\
\hline & & & Fluorides & & \\
\hline & & & $\mathrm{Fe}$ & 1,02 & \\
\hline & & & $\mathrm{Pb}$ & & \\
\hline & & & $\mathrm{Hg}$ & & \\
\hline & & & $\mathrm{Ni}$ & & \\
\hline & & & Zinc & & \\
\hline & & uts to nature $(b$ & IWM-2 calculations) & & \\
\hline & Emissions to & & Emissions & $\operatorname{ter}[\mathrm{kg}]$ & \\
\hline 总 & Particulates & -254.20 & BOD & & \\
\hline 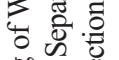 & $\mathrm{CO}$ & -296.77 & COD & -87 & \\
\hline 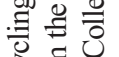 & $\mathrm{CO}_{2}$ & $-69,592.11$ & Suspended solids & $-2,0$ & \\
\hline 赵 & $\mathrm{CH}_{4}$ & -8.61 & TOC & & \\
\hline
\end{tabular}


Table 2. Continued.

\begin{tabular}{|c|c|c|c|c|}
\hline & \multicolumn{4}{|c|}{ Outputs to nature (based on IWM-2 calculations) } \\
\hline & \multicolumn{2}{|c|}{ Emissions to air $[\mathrm{kg}]$} & \multicolumn{2}{|c|}{ Emissions to water $[\mathrm{kg}]$} \\
\hline \multirow{18}{*}{ 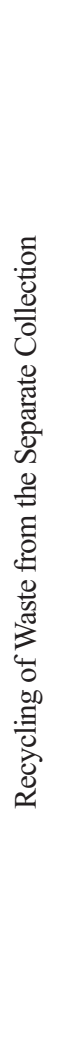 } & $\mathrm{NO}_{\mathrm{x}}$ & 169.91 & $\mathrm{AOX}$ & -9.19 \\
\hline & $\mathrm{N}_{2} \mathrm{O}$ & 0.92 & Phenols & -0.10 \\
\hline & $\mathrm{SO}_{\mathrm{x}}$ & -696.64 & $\mathrm{Al}$ & -1.28 \\
\hline & $\mathrm{HCl}$ & -17.29 & $\mathrm{NH}_{4}^{+}$ & -9.30 \\
\hline & $\mathrm{HF}$ & 4.59 & As & -0.01 \\
\hline & $\mathrm{H}_{2} \mathrm{~S}$ & 0.06 & $\mathrm{Ba}$ & -1.67 \\
\hline & Ammonia & -0.83 & $\mathrm{Cd}$ & -0.02 \\
\hline & Arsenic & -18.58 & Chlorides & $-2,448.37$ \\
\hline & Lead & 14.20 & $\mathrm{Cr}$ & -0.04 \\
\hline & Nickel & -0.03 & $\mathrm{Cu}$ & 0.02 \\
\hline & Zinc & -0.03 & $\mathrm{Fe}$ & -2.03 \\
\hline & & & $\mathrm{Pb}$ & -0.11 \\
\hline & & & $\mathrm{Ni}$ & -0.02 \\
\hline & & & Nitrates (V) & 16.02 \\
\hline & & & Phosphates & 0.28 \\
\hline & & & Sulphur & 74.05 \\
\hline & & & Sulphides & -0.02 \\
\hline & & & Zinc & -0.03 \\
\hline
\end{tabular}

Source: Primary data taken from the Municipal Waste Management Company in Kielce and IWM-2

Table 4 presents the cumulative value of eco-indicators divided into three damage categories: human health, ecosystem quality, and resources. Analysis of the results presented in Table 4 indicates the following:

- For each damage category, the result for LCA2 is less "environmentally friendly"

- The difference in the results is particularly evident in the case of human health, for which the result for LCA2 was $812,916 \mathrm{Pt}$, which is more than six times higher than the result for LCA1 (124,442 Pt)

- For ecosystem quality the difference between the results is 36,269 $\mathrm{Pt}$ and the potential impact calculated for LCA2 is almost 10 times higher (LCA1 $=4,107 \mathrm{Pt}$, $\mathrm{LCA} 2=40,376 \mathrm{Pt}$ )

- For resources there is an environmental benefit in LCA1 amounting to $-32,948 \mathrm{Pt}$, while for LCA2 the indicator result is positive and amounts to 5,123 $\mathrm{Pt}$.

Table 5 shows characterized LCIA results for the impact category in each of the damage categories. There is a difference in the potential impact results for the indicator calculated for carcinogens. For LCA2 this result was 31.67 DALY and pointed to a negative impact, while for LCA1 the final balance of impact for carcinogens pointed to an environmental benefit of -0.98 DALY. Table 5 also shows that there are two impact categories belonging to human health in which the results of the indicators for LCA2 were better than for LCA1: respiratory disorders resulting from the emission of organic compounds and climate change.

Different results were also obtained with regard to the impact category belonging to ecosystem quality (Table 6). The difference is particularly evident for ecotoxicity, where the outcome indicator for LCA2 is more than 75 times higher than for LCA1. In the case of acidification/eutrophication, LCA1 indicates environmental benefit, while in LCA2 there was a positive result (negative impact on the environment).

A relatively small difference was obtained for minerals as an impact category belonging to the use of resources (Table 7). Both cases show benefits for the environment, but lower than for LCA2.

For fossil fuels, the difference in the results obtained is much clearer. The impact category indicator result for LCA1 is six times higher than the value obtained for LCA2. Finally the LCA1 scenario generated a positive impact, while the LCA2 case impacted negatively on the environment.

\section{Analysis of the LCIA Results}

Different results relating to environmental impact were obtained in the analyses carried out for the same functional unit and given data. In order to find out why this happened, it is necessary to look deeper into the specific char- 
Table 3. The inventory data used as inputs in the calculations made in SimaPro (LCA2).

\begin{tabular}{|c|c|c|c|}
\hline & Inventory Point & Quantity & Unit \\
\hline \multirow{6}{*}{ 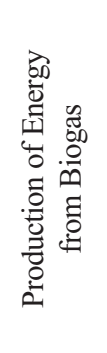 } & Avoided products & & \\
\hline & Heat, from natural gas, at industrial furnace & $6,003.52$ & MWh \\
\hline & Electricity, low voltage, at grid, Poland production mix & $2,572.94$ & MWh \\
\hline & Own production & & \\
\hline & Electricity from biogas (partially used for own purposes, partially sold to the electricity grid) & $2,572.94$ & MWh \\
\hline & Heat from biogas (partially used for own purposes, partially sold to the heat grid) & $6,003.52$ & MWh \\
\hline \multirow{7}{*}{ 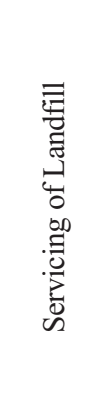 } & \multicolumn{3}{|l|}{ Inputs from nature } \\
\hline & Land transformation & 4.60 & ha \\
\hline & Land occupation & 0.38 & ha*a \\
\hline & Inputs from technosphere & & \\
\hline & Water & 333.00 & $\mathrm{Mg}$ \\
\hline & Diesel oil & 65.00 & $\mathrm{Mg}$ \\
\hline & Electricity low voltage, at grid, Poland production mix (purchased ) & 86.00 & MWh \\
\hline \multirow{12}{*}{ 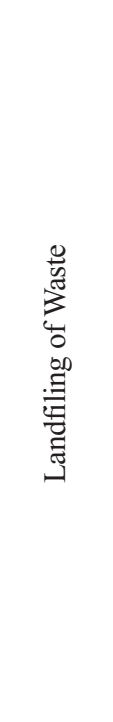 } & Avoided products/processes & & \\
\hline & gravel (as a result of using waste concrete) & $2,090.10$ & $\mathrm{Mg}$ \\
\hline & Waste to treatment & & \\
\hline & Composition of mixed municipal waste: & & \\
\hline & paper, packaging paper, and paperboard & $9,765.90$ & $\mathrm{Mg}$ \\
\hline & glass & 17,87 & $\mathrm{Mg}$ \\
\hline & plastic (film) & $9,374.14$ & $\mathrm{Mg}$ \\
\hline & plastic (rigid) & $1,400.73$ & $\mathrm{Mg}$ \\
\hline & non-ferrous metals & $1,729.70$ & $\mathrm{Mg}$ \\
\hline & ferrous & $1,729.70$ & $\mathrm{Mg}$ \\
\hline & biodegradable waste ( $94.5 \%$ vegetable waste, $5.5 \%$ animal waste) & $14,414.60$ & $\mathrm{Mg}$ \\
\hline & mineral and other & $15,783.90$ & $\mathrm{Mg}$ \\
\hline \multirow{6}{*}{ 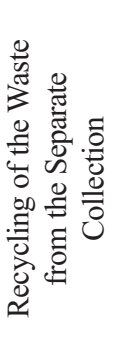 } & Waste to treatment & & \\
\hline & The composition of the waste collected separately (destined for recycling): & & \\
\hline & paper, packaging paper, and paperboard & 23.10 & $\mathrm{Mg}$ \\
\hline & glass & 310.60 & $\mathrm{Mg}$ \\
\hline & plastic (film) & 18.99 & $\mathrm{Mg}$ \\
\hline & plastic (rigid) & 23.21 & $\mathrm{Mg}$ \\
\hline
\end{tabular}

Source: Primary data taken from the Municipal Waste Management Company in Kielce

acteristics of the software and databases. The differentiating factor for these two studies could not be the methodology for calculation of the potential impact on the environment, because the same method Ecoindictor'99 H/A v. 2.06 was used in both cases. Therefore, one must suspect that the cause of these discrepancies was the different inventory data and the various assumptions adopted for their calculation.
In order to illustrate the potential reasons for the differences in results, Tables 8 and 9 present the following information:

- The number of substances included in the inventory analysis (LCI) as emissions to the three environmental compartments (air, water, and soil) and as the consumption of raw materials (with an indication of how many of them generate a negative impact on the environment 
Table 4. Weighted damage category indicator results for treating $72,448.6 \mathrm{Mg}$ of municipal waste according to LCA1 and LCA2.

\begin{tabular}{|c|c|c|c|}
\hline $\begin{array}{c}\text { Damage } \\
\text { Category }\end{array}$ & $\begin{array}{c}\text { Human Health } \\
{[\mathrm{Pt}]}\end{array}$ & $\begin{array}{c}\text { Ecosystem } \\
\text { Quality [Pt] }\end{array}$ & $\begin{array}{c}\text { Resources } \\
{[\mathrm{Pt}]}\end{array}$ \\
\hline LCA1 & 124,442 & 4,107 & $-32,948$ \\
\hline LCA2 & 812,916 & 40,376 & 5,123 \\
\hline
\end{tabular}

= positive indicator "+" and how many an environmental benefit = negative indicator "-")

- The total weight included in the analyses of emissions and raw materials consumed - the values reported are the result of the addition of emissions and the raw materials and are expressed in units of mass (with the exception of radioactive and energy emissions and land surface). A negative result means that the emissions or the raw materials in the framework of the so-called avoided products exceeded in value the emissions and consumption of resources

- The number of substances included in the LCIA as emissions to the three environmental compartments (air, water, and soil) and the consumption of raw materials

- Potential environmental impacts caused by all emissions and raw materials

As shown in the section Life Cycle Impact Assessment (LCIA) Results, the main difference in the results obtained from the LCIA appeared in four impact categories relating to emissions: carcinogens, climate change, ecotoxicity, and eutrophication/acidification, and for one input-related impact category - fossil fuels. Tables 8 and 9 highlight the following issues:

- The IWM-2 program identified a smaller number of substances emitted to air and water associated with landfill and recycling than the Ecoinvent database (IWM-2 identified a total of 31 types of emissions to air and water for landfill while Ecoinvent identified 405 types, IWM-2 identified 39 types of emissions for recycling while Ecoinvent identified 403 types)

- The IWM-2 program did not cover emissions to the soil, while the Ecoinvent database identified 60 types of such impact for landfill and 58 for recycling

- The IWM-2 program does not cover consumption of resources, while the Ecoinvent database covered the use of 198 kinds of raw material (including 100 different minerals and fossil fuels)

- In each case a different total mass of emissions and resources consumed was identified in the analysis of the inventory included in both analyses

The issue of different quantities of inventory data contained in the Ecoinvent v.2.0 databases and databases belonging to the IWM-2 is also linked to the issue of recycling. In both cases, the procedure for recycling was based on the same idea of compiling environmental impacts and related impacts from the avoided use of products (which often prevent the use of raw materials which would otherwise be necessary) with environmental impacts associated with the use of recycled materials and recycling processes. Avoided products generate an environmental benefit (a negative indicator), and the second elements lead to negative environmental impacts (a positive indicator). The sign and value of the final outcome of an environmental indicator therefore depend on the relationship between these two areas. Table 8 shows that in the analysis of the inventory for the landfill program IWM-2 identified 12 substances emitted to the air with a total weight of $5,169,835.14 \mathrm{~kg}$, which were all emissions generating a positive indicator ("+"), so leading to a potential negative impact on the environment. For the same process, the SimaPro software, based on the Ecoinvent v.2.0 database, showed 231 substances emitted

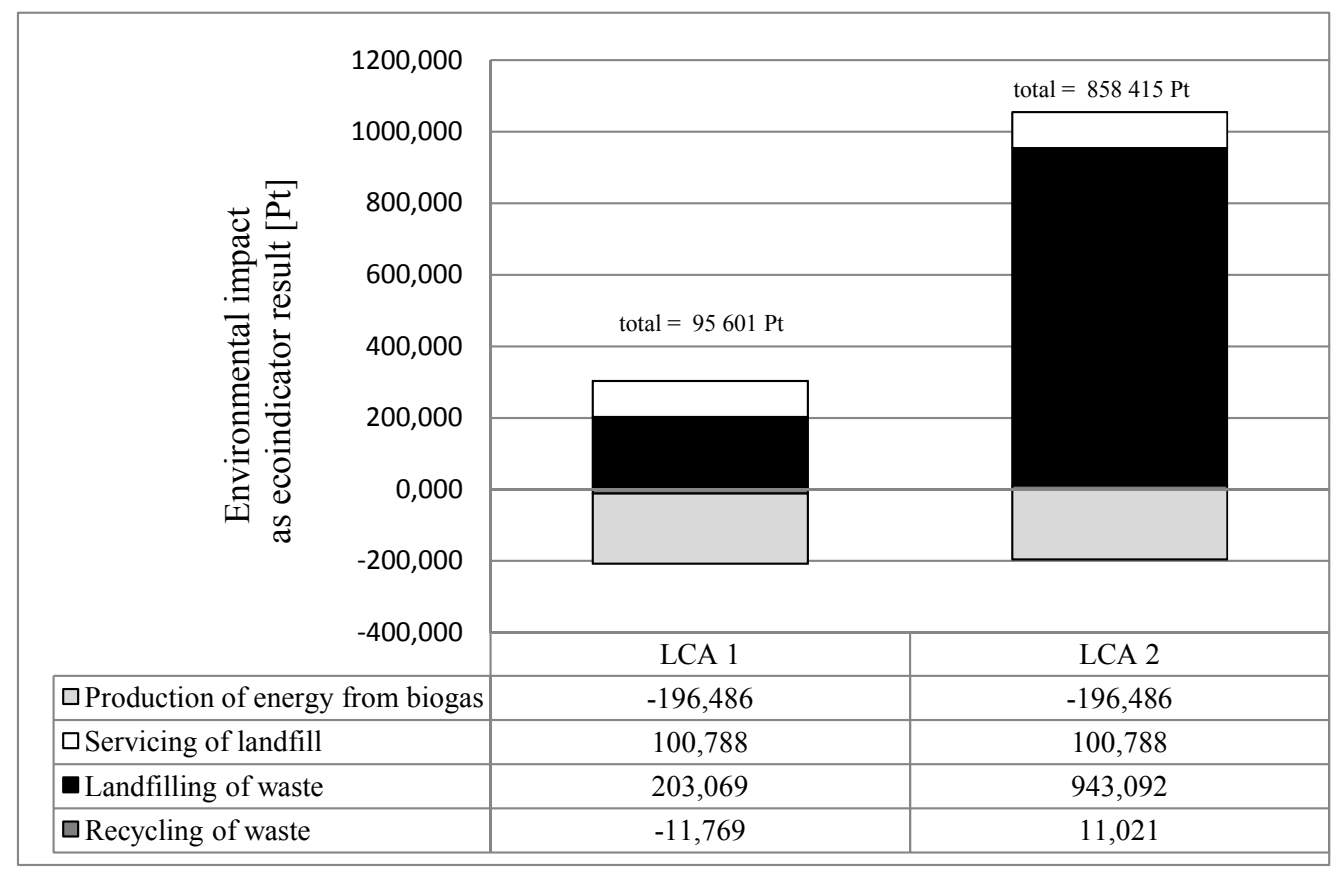

Fig. 4. Ecoindicator results for treating 72,448.6 Mg municipal waste in Promnik - according to LCA1 and LCA2 scenarios. 
Table 5. Human health - impact category indicator results for treating of 72,448.6 Mg municipal waste according to LCA1 and LCA2.

\begin{tabular}{|c|c|c|c|c|c|c|}
\hline $\begin{array}{c}\text { Impact } \\
\text { Category }\end{array}$ & $\begin{array}{c}\text { Carcinogens } \\
{[\mathrm{DALY}]}\end{array}$ & $\begin{array}{c}\text { Resp. Organics } \\
{[\mathrm{DALY}]}\end{array}$ & $\begin{array}{c}\text { Resp. Inorganics } \\
{[\mathrm{DALY}]}\end{array}$ & $\begin{array}{c}\text { Climate change } \\
{[\mathrm{DALY}]}\end{array}$ & $\begin{array}{c}\text { Radiation } \\
{[\mathrm{DALY}]}\end{array}$ & $\begin{array}{c}\text { Ozone layer } \\
{[\mathrm{DALY}]}\end{array}$ \\
\hline LCA1 & -0.98 & 0.04 & -1.20 & 6.91 & -0.0002 & 0.00002 \\
\hline LCA2 & 31.67 & -0.002 & -0.25 & -0.20 & 0.002 & 0.0002 \\
\hline
\end{tabular}

Table 6. Ecosystem quality - impact category indicator results for treating 72,448.6 Mg of municipal waste according to LCA1 and LCA2 (impact categories within).

\begin{tabular}{|c|c|c|c|}
\hline Impact Category & $\begin{array}{c}\text { Ecotoxicity } \\
{\left[\mathrm{PDF} \cdot \mathrm{m}^{2} \cdot \mathrm{yr}\right]}\end{array}$ & $\begin{array}{c}\text { Acidification/Eutrophication } \\
{\left[\mathrm{PDF} \cdot \mathrm{m}^{2} \cdot \mathrm{yr}\right]}\end{array}$ & $\begin{array}{c}\text { Land use } \\
{\left[\mathrm{PDF} \cdot \mathrm{m}^{2} \cdot \mathrm{yr}\right]}\end{array}$ \\
\hline LCA1 & $-5,223$ & $-19,379$ & 77,258 \\
\hline LCA2 & 393,374 & 53,112 & 71,158 \\
\hline
\end{tabular}

Table 7. Resources - impact category indicator results for treating $72,448.6 \mathrm{Mg}$ of municipal waste according to LCA1 and LCA2.

\begin{tabular}{|c|c|c|}
\hline $\begin{array}{c}\text { Impact } \\
\text { Category }\end{array}$ & $\begin{array}{c}\text { Minerals } \\
\text { [MJ Surplus] }\end{array}$ & $\begin{array}{c}\text { Fossil fuels } \\
\text { [MJ Surplus] }\end{array}$ \\
\hline LCA1 & $-22,512$ & $-1,361,842$ \\
\hline LCA2 & $-8,185$ & 223,446 \\
\hline
\end{tabular}

to the air, of which 223 were emissions with a positive value and 8 with a negative value of the indicator. The result of the mass emissions to the air equal to 8,722,201.53 $\mathrm{kg}$ is the effect of the addition to the positive and negative values, which means that the value of the emissions to the air of 223 substances adversely affecting the environment massively outweighed the 8 substances that lead to environmental benefits. In the case of a landfill, environmental benefits were estimated for the use of waste concrete in place of gravel (which was treated as an avoided product).

Due to the fact that there are parameters developed for characterizing a limited number of elementary streams (emissions and inputs to/from the environment) in the LCIA methods available, in practice not all the inventory results are assessed in field of impact on the environment. In Tables 8 and 9 this problem is illustrated in the first and third lines within each category of emissions. For example, in LCA1 for landfill, 12 substances are identified as being emitted into the air, of which only 9 were from the LCIA analysis. In the case of LCA2 in the Ecoindicator'99 H/A method, characterization parameters were present for 130 of the 231 air emissions identified. These limits could also have an impact on the range of results. Table 8 shows that in the case of landfill, the Ecoinvent database v.2.0 identified many more emissions to water and soil as well as types of consumption of resources than IWM-2, which directly leads to higher environmental performance. Exceptions include some air emissions; despite the fact that in the LCIA analysis of LCA1 only 9 emissions were taken into account, they caused a much higher score for the environmental indicator.
There are two explanations for this state of affairs. The first is the taking into account of the avoided consumption of gravel as an avoided product in LCA2, which resulted in 73 types of emissions to the air with a negative sign and their value decreased the result of a positive indicator. A second possibility is that the LCA1 emissions included have greater environmental significance (higher values of indicators for environmental hazard). Further analysis shows that both of these situations overlapped with one another in the studies carried out and reinforce each other's performance.

The recycling results require additional comment (Table 9). In the case of the emissions to air and water, SimaPro and IWM-2 not only calculated different amounts of substances emitted, but also the final results have a different sign. This is a result of the variations in the proportion of aspects generating a positive and negative impact on the environment. In the case of LCA1 the positive elements predominated, and in LCA2 glass recycling processes generate greater negative impact than the benefit to the environment due to the avoided use of virgin glass-forming raw materials. To further illustrate the source of the differences in the results, a detailed analysis was carried out for the impact of the carcinogens category, for which the LCIA achieved significantly different results. In the Ecoindicator'99 H/A method elementary streams initiating the impact in carcinogens are emissions to air, water, and soil. Table 10 presents the share of each emissions sector in the creation of carcinogen impact in the landfill process.

In the LCA1 study, only cadmium was recognized as a carcinogenic emission to the air at a level of $0.038 \mathrm{~kg}$ (Tables 2 and 10), which has a negative impact on the environment at a level of $133.6 \mathrm{Pt}(0.00513 \mathrm{DALY})$. In the LCA2 study, up to 25 substances were recognized as carcinogenic emissions to the air, 24 of which were "negative" emissions (positive environmental indicator), and one a "positive" (negative environmental indicator) with a total mass equal to $33.6 \mathrm{~kg}$ (positive emissions subtracted from negative). Despite the recognition of 24 times more cancercausing emissions, the cumulative result for the environmental indicator for emissions to air was comparable in 
Table 8. Landfill of waste - the differences between LCA1 and LCA2 in LCI and LCIA results for the selected inventory elements.

\begin{tabular}{|c|c|c|c|c|}
\hline \multicolumn{5}{|c|}{ Landfill of Waste (72,072.7 Mg of waste) } \\
\hline \multicolumn{2}{|r|}{ Characteristics of the key inventory elements } & LCA1 & LCA2 & Unit \\
\hline \multirow{4}{*}{$\begin{array}{l}\text { Emissions } \\
\text { to Air }\end{array}$} & $\begin{array}{l}\text { Number of substances emitted to the air and included in the inven- } \\
\text { tory analysis (LCI) }\end{array}$ & $\begin{array}{c}12 \\
\text { where: }+12 ;-0\end{array}$ & $\begin{array}{c}231 \\
\text { where: }+223 ;-8\end{array}$ & $\mathrm{n} / \mathrm{a}$ \\
\hline & $\begin{array}{l}\text { Total mass of emissions to the air } \\
\text { (including only emissions expressed in mass units) }\end{array}$ & $5,169,835.14$ & $8,722,201.53$ & $\mathrm{~kg}$ \\
\hline & $\begin{array}{l}\text { Number of substances emitted to the air and included in the impact } \\
\text { assessment (LCIA) }\end{array}$ & $\begin{array}{c}9 \\
\text { where: }+9 ;-0\end{array}$ & $\begin{array}{c}130 \\
\text { where: }+127 ;-3\end{array}$ & $\mathrm{n} / \mathrm{a}$ \\
\hline & $\begin{array}{l}\text { Total environmental impact of emissions to the air } \\
\text { (as ecoindicator result) }\end{array}$ & $202,484.1$ & $37,981.6$ & $\mathrm{Pt}$ \\
\hline \multirow{4}{*}{$\begin{array}{l}\text { Emissions } \\
\text { to Water }\end{array}$} & $\begin{array}{l}\text { Number of substances emitted to water and included in the invento- } \\
\text { ry analysis (LCI) }\end{array}$ & $\begin{array}{c}19 \\
\text { where: }+16 ;-3\end{array}$ & $\begin{array}{c}174 \\
\text { where: }+172 ;-2\end{array}$ & $\mathrm{n} / \mathrm{a}$ \\
\hline & $\begin{array}{c}\text { Total mass of emissions to water } \\
\text { (including only emissions expressed in mass units) }\end{array}$ & $27,545.1$ & $15,182,111.41$ & $\mathrm{~kg}$ \\
\hline & $\begin{array}{l}\text { Number of substances emitted to water and included in the impact } \\
\text { assessment (LCIA) }\end{array}$ & $\begin{array}{c}8 \\
\text { where: }+8 ;-0\end{array}$ & $\begin{array}{c}36 \\
\text { where: }+36 ;-0\end{array}$ & $\mathrm{n} / \mathrm{a}$ \\
\hline & $\begin{array}{l}\text { Total environmental impact of emissions to water } \\
\text { (as ecoindicator result) }\end{array}$ & 584.6 & $771,155.58$ & $\mathrm{Pt}$ \\
\hline \multirow{4}{*}{$\begin{array}{l}\text { Emissions } \\
\text { to Soil }\end{array}$} & $\begin{array}{l}\text { Number of substances emitted to the soil and included in the } \\
\text { inventory analysis (LCI) }\end{array}$ & 0 & $\begin{array}{c}60 \\
\text { where: }+60 ;-0\end{array}$ & $\mathrm{n} / \mathrm{a}$ \\
\hline & $\begin{array}{c}\text { Total mass of emissions to the soil } \\
\text { (including only emissions expressed in mass units) }\end{array}$ & 0 & $517,151.22$ & $\mathrm{~kg}$ \\
\hline & $\begin{array}{l}\text { Number of substances emitted to the soil and included in the } \\
\text { impact assessment (LCIA) }\end{array}$ & 0 & $\begin{array}{c}14 \\
\text { where: }+14 ;-0\end{array}$ & $\mathrm{n} / \mathrm{a}$ \\
\hline & $\begin{array}{l}\text { Total environmental impact of emissions to the soil } \\
\text { (as ecoindicator result) }\end{array}$ & 0 & $99,210.96$ & $\mathrm{Pt}$ \\
\hline \multirow{4}{*}{$\begin{array}{l}\text { Resource } \\
\text { Depletion }\end{array}$} & $\begin{array}{l}\text { Number of types of raw material included in the inventory analysis } \\
\text { (LCI) }\end{array}$ & 0 & $\begin{array}{c}198 \\
\text { where: }+193 ;-5\end{array}$ & $\mathrm{n} / \mathrm{a}$ \\
\hline & $\begin{array}{l}\text { Total mass of resources included in the calculations } \\
\text { (including only raw materials expressed in mass units) }\end{array}$ & 0 & $5,708,818.26$ & $\mathrm{~kg}$ \\
\hline & $\begin{array}{l}\text { Number of types of raw material included in the impact assessment } \\
\text { (LCIA) }\end{array}$ & 0 & $\begin{array}{c}91 \\
\text { where: }+73 ;-18\end{array}$ & $\mathrm{n} / \mathrm{a}$ \\
\hline & $\begin{array}{l}\text { Environmental impact of the depletion of resources } \\
\text { (as ecoindicator result) }\end{array}$ & 0 & $34,743.8$ & $\mathrm{Pt}$ \\
\hline
\end{tabular}

LCA2 and LCA1. The reasons for the different results for carcinogens should therefore be traced to differences in the environmental impact of each emission. The LCA2 for a landfill of 72,072.7 tons using SimaPro based on the Ecoinvent database showed the existence of four main sources of negative impacts such as emissions of cadmium $(0.018 \mathrm{~kg})$, particulates $<2.5(168.6 \mathrm{~kg})$, arsenic $(0.03 \mathrm{~g})$, and dioxins in terms of 2,3,7,8-tetra-dioxin (1.03 mg), which generate an impact equal to $65.5 \mathrm{Pt}$ for cadmium, 42.9 Pt for particulates $(<2.5), 17.4 \mathrm{Pt}$ for arsenic, and 4.82 $\mathrm{Pt}$ for dioxins. The other 21 emissions to the air classified as carcinogenic had little environmental significance. What is more, IWM-2, whose impact was limited solely to cad- mium emissions but in a significant quantity equal to 0.038 $\mathrm{kg}$, showed a comparable outcome indicator (Pt 133.6) to all the emissions included in the LCA2 (134.3 Pt).

In the case of carcinogenic emissions to water and soil, the relationship seems to be more obvious. The Ecoinvent database contains much more of this type of impact from the database contained in IWM-2, which in turn gave a much higher environmental performance. The main sources of carcinogens were the processes of landfilling plastics and bio-waste in anaerobic decomposition. Emissions of cadmium and arsenic in water (LCA1, LCA2) and soil (LCA2) contributed almost $100 \%$ of the negative impact. 
Table 9. Recycling of the waste fractions coming from separate collection - differences between LCA1 and LCA2 in LCI and LCIA results for selected inventory elements.

\begin{tabular}{|c|c|c|c|c|}
\hline \multicolumn{5}{|c|}{ Recycling of the Waste Fractions Coming from Separate Collection (375.9 Mg of waste) } \\
\hline & Characteristics of the key inventory elements & LCA1 & LCA2 & Unit \\
\hline \multirow{4}{*}{$\begin{array}{l}\text { Emissions } \\
\text { to Air }\end{array}$} & $\begin{array}{l}\text { Number of substances emitted to the air and included in the inven- } \\
\text { tory analysis (LCI) }\end{array}$ & $\begin{array}{c}16 \\
\text { where: }+5 ;-11\end{array}$ & $\begin{array}{c}229 \\
\text { where: }+182 ;-47\end{array}$ & $\mathrm{n} / \mathrm{a}$ \\
\hline & $\begin{array}{l}\text { Total mass of emissions to the air } \\
\text { (including only emissions expressed in mass units) }\end{array}$ & $-70,695.40$ & $232,665.26$ & $\mathrm{~kg}$ \\
\hline & $\begin{array}{l}\text { Number of substances emitted to the air and included in the impact } \\
\text { assessment (LCIA) }\end{array}$ & $\begin{array}{c}12 \\
\text { where: }+2 ;-10\end{array}$ & $\begin{array}{c}128 \\
\text { where: }+116 ;-12\end{array}$ & $\mathrm{n} / \mathrm{a}$ \\
\hline & $\begin{array}{l}\text { Total environmental impact of emissions to the air } \\
\text { (as ecoindicator result) }\end{array}$ & - $11,715.7$ & $6,843.0$ & $\mathrm{Pt}$ \\
\hline \multirow{4}{*}{$\begin{array}{l}\text { Emissions } \\
\text { to Water }\end{array}$} & $\begin{array}{l}\text { Number of substances emitted to water and included in the } \\
\text { inventory analysis (LCI) }\end{array}$ & $\begin{array}{c}23 \\
\text { where: }+6 ;-17\end{array}$ & $\begin{array}{c}174 \\
\text { where: }+147 ;-27\end{array}$ & $\mathrm{n} / \mathrm{a}$ \\
\hline & $\begin{array}{c}\text { Total mass of emissions to water } \\
\text { (including only emissions expressed in mass units) }\end{array}$ & $-5,185.6$ & $3,956.7$ & $\mathrm{~kg}$ \\
\hline & $\begin{array}{l}\text { Number of substances emitted to water and included in the impact } \\
\text { assessment (LCIA) }\end{array}$ & $\begin{array}{c}7 \\
\text { where: }+1 ;-6\end{array}$ & $\begin{array}{c}36 \\
\text { where: }+34 ;-2\end{array}$ & $\mathrm{n} / \mathrm{a}$ \\
\hline & $\begin{array}{l}\text { Total environmental impact of emissions to water } \\
\text { (as ecoindicator result) }\end{array}$ & -53.5 & 630.0 & $\mathrm{Pt}$ \\
\hline \multirow{4}{*}{$\begin{array}{l}\text { Emissions } \\
\text { to Soil }\end{array}$} & $\begin{array}{l}\text { Number of substances emitted to the soil and included in the } \\
\text { inventory analysis (LCI) }\end{array}$ & 0 & $\begin{array}{c}58 \\
\text { where: }+53 ;-5\end{array}$ & $\mathrm{n} / \mathrm{a}$ \\
\hline & $\begin{array}{l}\text { Total mass of emissions to the soil } \\
\text { (including only emissions expressed in mass units) }\end{array}$ & 0 & 182.0 & $\mathrm{~kg}$ \\
\hline & $\begin{array}{l}\text { Number of substances emitted to the soil and included in the impact } \\
\text { assessment (LCIA) }\end{array}$ & 0 & $\begin{array}{c}14 \\
\text { where:+14; }-0\end{array}$ & $\mathrm{n} / \mathrm{a}$ \\
\hline & $\begin{array}{l}\text { Total environmental impact of emissions to the soil } \\
\text { (as ecoindicator result) }\end{array}$ & 0 & 413.9 & $\mathrm{Pt}$ \\
\hline \multirow{4}{*}{$\begin{array}{l}\text { Resource } \\
\text { Depletion }\end{array}$} & $\begin{array}{l}\text { Number of types of raw material included in the inventory analysis } \\
\text { (LCI) }\end{array}$ & 0 & $\begin{array}{c}198 \\
\text { where: }+135 ;-63\end{array}$ & $\mathrm{n} / \mathrm{a}$ \\
\hline & $\begin{array}{l}\text { Total mass of resources included in the calculations } \\
\text { (including only raw materials expressed in mass units) }\end{array}$ & 0 & $33,205.57$ & $\mathrm{~kg}$ \\
\hline & $\begin{array}{l}\text { Number of types of raw material included in the impact assessment } \\
\text { (LCIA) }\end{array}$ & 0 & $\begin{array}{c}91 \\
\text { where: }+53 ;-38\end{array}$ & $\mathrm{n} / \mathrm{a}$ \\
\hline & $\begin{array}{l}\text { Environmental impact of the depletion of resources } \\
\text { (as ecoindicator result) }\end{array}$ & 0 & $3,134.5$ & $\mathrm{Pt}$ \\
\hline
\end{tabular}

Similar relationships can be applied to other impact categories such as ecotoxicity, acidification/eutrophication, or minerals.

\section{Discussion}

The research carried out has shown that having the same initial inventory data collected on the basis of the same assumptions and the same boundaries for the system modelled and using the same method of LCIA to assess the impact on the environment, may not produce the same end results. Due to the fact that the LCA analysis can be conducted in differently defined scope (from cradle to grave or cradle-to-gate or gate-to-grave), that is usually with a lesser or greater extent, the specific data collected must be supplemented with secondary data retrieved from the database. Its quantity and quality may have an important impact on the final results. There are some particularly important issues from the point of view of final waste management such as the time horizon for modelling the impact, the taking into account of the infrastructure, and avoided products. In the case of the databases included in IWM-2, emissions 
Table 10. Carcinogens - differences in LCI and LCIA results for selected inventory elements between LCA1 and LCA2.

\begin{tabular}{|c|c|c|c|c|}
\hline \multicolumn{5}{|c|}{ Carcinogens - Landfill of Waste $(72,072.7 \mathrm{Mg}$ of waste) } \\
\hline \multicolumn{2}{|r|}{ Characteristics of carcinogenic emissions } & \multirow{2}{*}{$\begin{array}{c}\text { LCA1 } \\
1 \\
\text { where: }+1 ;-0\end{array}$} & \multirow{2}{*}{$\begin{array}{c}\text { LCA2 } \\
25 \\
\text { where: }+24 ;-1\end{array}$} & \multirow{2}{*}{$\begin{array}{l}\text { Unit } \\
\mathrm{n} / \mathrm{a}\end{array}$} \\
\hline \multirow{4}{*}{$\begin{array}{l}\text { Emissions } \\
\text { to Air }\end{array}$} & $\begin{array}{l}\text { Number of substances emitted to the air and included in the impact } \\
\text { assessment (LCIA) for carcinogens }\end{array}$ & & & \\
\hline & $\begin{array}{l}\text { Total mass of the emissions to the air classified as carcinogens } \\
\text { (including only emissions expressed in mass units) }\end{array}$ & 0,038 & 180,5 & $\mathrm{~kg}$ \\
\hline & $\begin{array}{l}\text { Total environmental impact of emissions to the air } \\
\text { (as ecoindicator result for carcinogens) }\end{array}$ & 133,6 & 134,3 & $\mathrm{Pt}$ \\
\hline & $\begin{array}{l}\text { Total environmental impact of emissions to the air } \\
\text { (as impact category indicator result for carcinogens) }\end{array}$ & 0,00513 & 0,00515 & DALY \\
\hline \multirow{4}{*}{$\begin{array}{l}\text { Emissions } \\
\text { to Water }\end{array}$} & $\begin{array}{l}\text { Number of substances emitted to water and included in the impact } \\
\text { assessment (LCIA) for carcinogens }\end{array}$ & $\begin{array}{c}3 \\
\text { where: }+3 ;-0\end{array}$ & $\begin{array}{c}15 \\
\text { where: }+15 ;-0\end{array}$ & $\mathrm{n} / \mathrm{a}$ \\
\hline & $\begin{array}{l}\text { Total mass of emissions to water classified as carcinogens } \\
\text { (including only emissions expressed in mass units) }\end{array}$ & 2,1 & 687,3 & $\mathrm{~kg}$ \\
\hline & $\begin{array}{l}\text { Total environmental impact of emissions to water } \\
\text { (as ecoindicator result for carcinogens) }\end{array}$ & 538 & 738986,80 & $\mathrm{Pt}$ \\
\hline & $\begin{array}{l}\text { Total environmental impact of emissions to water } \\
\text { (as impact category indicator result for carcinogens) }\end{array}$ & 0,0207 & 28,4 & DALY \\
\hline \multirow{4}{*}{$\begin{array}{l}\text { Emissions } \\
\text { to Soil }\end{array}$} & $\begin{array}{l}\text { Number of substances emitted to the soil and included in the impact } \\
\text { assessment (LCIA) for carcinogens }\end{array}$ & 0 & $\begin{array}{c}4 \\
\text { where: }+7 ;-0\end{array}$ & $\mathrm{n} / \mathrm{a}$ \\
\hline & $\begin{array}{l}\text { Total mass of emissions to the soil classified as carcinogens } \\
\text { (including only emissions expressed in mass units) }\end{array}$ & 0 & 42,7 & $\mathrm{~kg}$ \\
\hline & $\begin{array}{l}\text { Total environmental impact of emissions to the soil } \\
\text { (as ecoindicator result for carcinogens) }\end{array}$ & 0 & 98531,40 & $\mathrm{Pt}$ \\
\hline & $\begin{array}{l}\text { Total environmental impact of emissions to the soil } \\
\text { (as impact category indicator result for carcinogens) }\end{array}$ & 0 & 3,78 & DALY \\
\hline
\end{tabular}

to air and water from the landfill were calculated over a 40year time horizon, while the Ecoinvent v.2.0 database used includes emissions over 100 years, and emissions to groundwater were modelled over the long term [12]. So, it must be emphasized that the IWM-2 base calculated significantly higher emissions of cadmium into the air for landfill than was the case with SimaPro based on Ecoinvent data. Another important element of environmental impact is the taking into account of the provision of infrastructure facilities and waste management processes. It can be assumed that if the inventory database takes infrastructure issues which provide a relatively solid background for the results, more into account, this may reduce the sensitivity of the results to change in other system components such as the morphological composition of the waste. Because the Ecoinvent database contains more information related to infrastructure, it can be treated as one of the possible causes of the lower sensitivity of the results to change in waste composition compared to IWM-2.

The end processes in waste management are inextricably linked to re-use, recycling, and energy recovery. The understanding of these processes and the way they are treated in the inventory tables plays an important role. The consequence of including this type of process is usually the treatment of those elements of the inventory corresponding to them and the results of the environmental assessment as the avoidance of negative impacts, which means that some of the results of the LCI and LCIA have a negative value. This may pose some difficulties in interpretation, because it is worth following closely what has a positive impact and what has a negative impact in the individual unit processes. In the systems analyzed there were three key elements responsible for creating environmental benefits: recycling processes (avoiding the need to use raw materials), production of energy from biogas (avoiding the need to use electricity and heat based on non-renewable energy sources from the centralized energy system) and the use of waste concrete (to avoid the need to use gravel). As shown by the analyses, different environmental benefits were calculated in the LCA1 and LCA2 studies, and to varying degrees this affected the final results.

\section{Conclusions}

Use of environmental impact assessment software and databases specific to the area being analyzed seems, in theory, to guarantee obtaining more accurate and reliable 
results. In the case of the LCA, taking into account the entire life cycle of products and using large amounts of data, the quality and quantity of inventory information is of particular importance. In the case of the analyses carried out, IWM-2 software - specific software for waste management - showed greater sensitivity to morphological change in the composition of waste, which on the one hand can be explained by the possession of information on the mass of mixed waste as a whole, not just as a collection of fractions, and on the other hand to holding poorer data related to, e.g., infrastructure issues. The weaker element of the IWM-2 package turned out to be the old database (ETSU 1992, 1993, IPCC 1994, 1996, Buwal 250/II 1998), in contrast to the rich and constantly updated Ecoinvent database. Both the programs used (IWM-2 and SimaPro) calculated significantly different results relating to the number and amount of emissions and the consumption of resources, and demonstrated the environmental benefits related to recycling of waste in different ways. The IWM-2 program identified a total of 31 types of emissions to air and water for landfill while Ecoinvent identified 405 types and IWM-2 identified 39 types of emissions for recycling while Ecoinvent identified 403 types. The IWM-2 program did not cover emissions to the soil, while the Ecoinvent database identified 60 types of such impact for landfill and 58 for recycling. The IWM-2 program does not cover consumption of resources, while the Ecoinvent database covered the use of 198 kinds of raw materials.

The final conclusion reached on the basis of the analyses may be that the choice of the calculation software (including the specific database and set of specific methods to assess the impact on the environment) used to assess the environmental impact of waste management systems is an important issue and that the information contained there should be the subject of regular updating and verification. When using LCA it is important to make a conscious choice of the databases and LCIA methods to be used with knowledge of the consequences of those decisions in the first and second phases of the LCA.

\section{References}

1. CENTRAL STATISTICAL OFFICE. Environment. Statistical information and elaborations, 2012. Central Statistical Office Report, Warsaw, 2012.

2. KULCZYCKA J., KOWALSKI Z., CHOLEWA M. Municipal waste management in Polish National and Local Plans. Czasopismo Techniczne Chemia. Wydawnictwo Politechniki Krakowskiej. 2008.

3. KULCZYCKA J., KOWALSKI Z. Valorisation of Packaging Waste Material - The Case of Poland. International Conference on Engineering for Waste and Biomass Valorisation in China, Beijing, 2010.

4. KULCZYCKA J., PIETRZYK-SOKULSKA E. Evaluation of municipal waste management in Poland. Wydawnictwo IGSMiE PAN, Kraków 2009.

5. DIRECTIVE 2008/98/EC of the European Parliament and of the Council of 19 November 2008 on waste and repealing certain Directives, 2008.
6. Waste management in European Union. The Office of the Committee of European Integration. 2003 [In Polish].

7. KONECZNY K., DRAGUSANU V., BERSANI R., PENNINGTON D.W. Environmental Assessment of Municipal Waste Management Scenarios.” European Commission, Joint Research Centre, Institute for Environment And Sustainability, Italy, 2007.

8. GENTIL E.C., DAMGAARD A., HAUSCHILD M., FINNVEDEN G., ERIKSSON O., THORNELOE S., KAPLAN P.O., BARLAZ M., MULLER O., MATSUI Y., RYOTA II, CHRISTENSEN T.H. Models for waste life cycle assessment: Review of technical assumptions. Waste Manage. 30, 2636, 2010.

9. WINKLER, J., BILITEWSKI, B. Comparative evaluation of life cycle assessment models for solid waste management, Waste Manage. 27, 1021, 2007.

10. CLEARY J. Life cycle assessments of municipal solid waste management systems: A comparative analysis of selected peer-reviewed literature. Environ. Int. 35, 1256, 2009.

11. CZARNECKA W., KULCZYCKA J., KOWALSKI Z. Basic principles of waste management in the municipal and economic sectors in the Świętokrzyskie Province in the years 2003-2006. Czasopismo Techniczne. Chemia. 2, 25, 2008.

12. www.ecoinvent.ch, accessed on: 01.08.2013.

13. MCDOUGALL F., WHITE P., FRANKE M., HINDLE P. Integrated solid waste management: a life cycle inventory. Blackwell Science, $2^{\text {nd }}$ Edition, pp. 544, 2003.

14. MENIKPURA S. N. M., GHEEWALA S.H., BONNET S. Sustainability assessment of municipal solid waste management in Sri Lanka: problems and prospects. J. Mater Cycles Waste Manag. 14, 181, 2013.

15. SONG Q., WANG Z., LI J., ZENG X. The life cycle assessment of an e-waste treatment enterprise in China. J. Mater Cycles Waste Manage. 15, 469, 2013.

16. AYE L., WIDJAYA E.R. Environmental and economic analyses of waste disposal options for traditional markets in Indonesia. Waste Manage. 26, 1180, 2006.

17. BANAR M., COKAYGIL Z., OZKAN A. Life cycle assessment of solid waste management options for Eskisehir, Turkey. Waste Manage. 29, 54, 2009.

18. BATOOL S.A., CHUADHRY. M. N. The impact of municipal solid waste treatment methods on greenhouse gas emissions in Lahore, Pakistan. Waste Manage. 29, 63, 2009.

19. BERNSTAD A., LA COUR JANSEN J. Review of comparative LCAs of food waste management systems - Current status and potential improvements. Waste Manage. 32, 2439, 2012.

20. BHANDER G. S., CHRISTENSEN T.H., HAUSCHILD M.Z. Easewaste - life cycle modelling capabilities for waste management technologies. Int. J Life Cycle Assess. 15, 403, 2010.

21. BJORKLUND A.E., FINNVEDEN G. Life cycle assessment of a national policy proposal - The case of a Swedish waste incineration tax. Waste Manage. 27, 1046, 2007.

22. BLENGINI G.A. Using LCA to evaluate impacts and resources conservation potential of composting: A case study of the Asti District in Italy. Resour Conserv Recy. 52, 1373, 2008.

23. BOLDRIN A., NEIDEL T.N., DAMGAARD A., BHANDER G.S., MØLLER J., CHRISTENSEN T.H. Modelling of environmental impacts from biological treatment of organic municipal waste in Easewaste. Waste Manage. 31, 619, 2011.

24. BRINKMANN A.J.F., SCHELLEMAN F.J.M. Strategic Environmental Assessment use in waste management planning. Guidelines and recommendations. EVD, Haga, 2005. 
25. BURNLEY S., PHILLIPS R., COLEMAN T. Carbon and life cycle implications of thermal recovery from the organic fractions of municipal waste. Int J Life Cycle Assess. 17, 1015, 2012.

26. BUTTOL P., MASONI P., BONOLI A., GOLDONI S., BELLADONNA V., CAVAZZUTI C. LCA of integrated MSW management systems: Case study of the Bologna District. Waste Manage. 27, 1059, 2007.

27. CHAYA W., GHEEWALA S.H. Life cycle assessment of MSW-to-energy schemes in Thailand. J Clean Prod. 15, 1463, 2007.

28. DE FEO G., MALVANO C. The use of LCA in selecting the best MSW management system. Waste Manage. 29, 1901, 2009.

29. DEN BOER E., JEDRCZAK A., KOWALSKI Z., KULCZYCKA J., SZPAD R. A review of municipal solid waste composition and quantities in Poland. Waste Manage. 30, 369, 2010

30. EL HANANDEH A., EL-ZEIN A. Strategies for the municipal waste management system to take advantage of carbon trading under competing policies: The role of energy from waste in Sydney. Waste Manage. 29, 2188, 2009.

31. EMERY A., ANTHONY DAVIES A., GRIFFITHS A., WILLIAMS K. Environmental and economic modelling: A case study of municipal solid waste management scenarios in Wales. Resour Conserv Recy. 49, 244, 2007.

32. ERIKSSON O., BISAILLON M. Multiple system modelling of waste management Waste Manage. 31, 2620, 2011.

33. GUERECA L.P., GASS'O S., BALDASANO J.M., JIM'ENEZ-GUERRERO P. Life cycle assessment of two biowaste management systems for Barcelona, Spain. Resour Conserv Recyc. 49, 32, 2006.
34. KHOO H.H. Life cycle impact assessment of various waste conversion Technologies. Waste Manage. 29, 1892, 2009

35. LUNDIE S., PETERS G.M. Life cycle assessment of food waste management options. J Clean Prod. 13, 275, 2005.

36. MANFREDI S., TONINI D., CHRISTENSEN T.H. Environmental assessment of different management options for individual waste fractions by means of life-cycle assessment modelling, Resour Conserv Recy. 55, 995, 2011.

37. ORTIZ O., PASQUALINO J.C., CASTELLS F. Environmental performance of construction waste: Comparing three scenarios from a case study in Catalonia, Spain, Waste Manage. 30, 646, 2010

38. SEONG-RIN LIM, SCHOENUNG J., M. Toxicity potentials from waste cellular phones, and a waste management policy integrating consumer, corporate, and government responsibilities, Waste Manage. 30, 1653, 2010.

39. SLAGSTAD H., BRATTEBØ H. Influence of assumptions about household waste composition in waste management LCAs, Waste Manage. 33, 212, 2013.

40. VALERIO F. Environmental impacts of post-consumer material managements: Recycling, biological treatments, incineration. Waste Manage. 30, 2354, 2010.

41. VERGARA S.E., DAMGAARD A., HORVATH A. Boundaries matter: Greenhouse gas emission reductions from alternative waste treatment strategies for California's municipal solid waste, Resour Conserv Recy. 57, 87, 2011.

42. DEN BOER E., DEN BOER J., JAGER J. Waste Management planning and optimisation. Handbook for municipal waste prognosis and sustainability assessment of waste management systems. LCA-IWM. Ibidem Verlag. pp. 306, 2007. 